\title{
PENGARUH PERBANDINGAN TEPUNG BERAS HITAM (Oryza sativa $L$. indica) DENGAN TERIGU TERHADAP KARAKTERISTIK BAKPAO
}

Effect of Ratio of Black Rice Flour (Oryza sativa L. indica) with Wheat Flour on the Characteristic of Bakpao

\author{
Rizky Rahmat Hidayat ${ }^{1}$, I Made Sugitha ${ }^{2}$, Anak Agung Istri Sri Wiadnyani ${ }^{2)}$ \\ ${ }^{1)}$ Mahasiswa Program Studi Imu dan Teknologi Pangan, Fakultas Teknologi Pertanian, Unud \\ ${ }^{2)}$ Dosen Program Studi Imu dan Teknologi Pangan, Fakultas Teknologi Pertanian, Unud \\ Kampus Bukit Jimbaran, Badung-Bali
}

\begin{abstract}
The purpose of study was to find the optimum ratio of black rice flour (Oryza sativa L. indica) with wheat to produce bakpao with the best characteristics. The Randomized Block Design (RBD) was used in the research with treatment that is the ratio of black rice flour with wheat which consist of 6 levels: 0\%:100\%, 5\%:95\%, 10\%:90\%, 15\%:85\%, 20\%:80\%, 25\%:75\%. The treatment was repeated 3 times to obtain 18 units of experiment. The data obtained were analyzed by variance and if the treatment had an effect on the observed variable then continued with Duncan Multiple Range Test (DMRT) test. The ratio of black rice flour to wheat had significant effect to protein content, fat content, IC50, texture, color (hedonic and scoring), texture (hedonic), taste (scoring) and overall acceptance (hedonic). Not Significant effect to moisture content, ash content, carbohydrate content, crude fiber content, texture (scoring) and taste (hedonic). The ratio of black rice flour and wheat (10\%:90\%) produces bakpao with the best characteristics namely: 37.44\% moisture content, $0.85 \%$ ash content, $7.46 \%$ protein content, $6.10 \%$ fat content, $48.15 \%$ carbohydrate content, $2.42 \%$ crude fiber content, swelling power $52.41 \%, I_{50} 41,48 \mathrm{~g} / 100 \mathrm{~g}$, texture $9.87 \mathrm{~N} / \mathrm{mm}$, grey color, rather soft texture, tasted rather like black rice, rather liked color and flavor, liked texture, taste and overall acceptability.
\end{abstract}

Keyword: bakpao, black rice, wheat, crude fiber, $I C_{50}$

\section{PENDAHULUAN}

Bakpao adalah makanan yang biasa dikonsumsi oleh masyarakat China, namun sekarang bakpao sudah sangat mendunia dan banyak dikonsumsi di berbagai negara salah satunya Indonesia. Bahan dasar pembuatan bakpao adalah terigu. Kandungan gizi yang terdapat didalam setiap $100 \mathrm{~g}$ bakpao adalah energi sebesar $239 \mathrm{kkal}$, protein 12,2 g, karbohidrat 41,6 g, lemak 2,6 g, kalsium 21 $\mathrm{mg}$, fosfor $65 \mathrm{mg}$ dan zat besi 2,8 mg. Bakpao juga mengandung vitamin A sebanyak $92 \mathrm{IU}$, vitamin B1 0,09 $\mathrm{mg}$ dan vitamin C $0 \mathrm{mg}$ (Hardiman dan Asmoro, 2014). Setiap tahun jumlah impor dan konsumsi terigu di

\footnotetext{
*Korespondensi Penulis:

E-mail: hrizkyrahmat@gmail.com ${ }^{1)}$
}

Indonesia semakin meningkat, oleh karena itu perlu adanya cara untuk mengurangi konsumsi terigu. Pemanfaatan bahan pangan lokal merupakan salah satu cara untuk mengurangi konsumsi terigu. Salah satu bahan pangan lokal yang dapat dilakukan substitusi dengan terigu adalah beras hitam.

Indonesia merupakan salah satu negara dengan konsumsi beras tertinggi di dunia, beras yang umumnya dikonsumsi oleh masyarakat di Indonesia adalah beras putih, beras merah dan beras hitam. Beras hitam merupakan salah satu jenis beras yang mempunyai nutrisi yang paling baik diantara jenis beras lainnya. Menurut Ichikawa dkk. (2001), beras hitam memiliki kandungan 
protein, vitamin dan mineral lebih tinggi dibanding dengan beras putih pada umumnya. Beras hitam mempunyai kandungan serat yang tinggi. Beras hitam mempunyai kandungan serat pangan dan hemiselulosa masing-masing sebesar $7,5 \%$ dan $5,8 \%$, sedangkan beras putih hanya sebesar $5,4 \%$ dan 2,2\% (Oki dkk., 2001 dalam Narwidina, 2009).

Beras hitam juga mengandung senyawa antosianin. Antosianin merupakan senyawa berwarna yang bertanggung jawab untuk sebagian warna kebanyakan warna merah, biru, dan ungu pada buah dan sayur. Senyawa ini termasuk dalam golongan flavonoid. Struktur utamanya ditandai dengan adanya dua cincin aromatik benzena $\left(\mathrm{C}_{6} \mathrm{H}_{6}\right)$ yang dihubungkan dengan tiga atom karbon yang berbentuk cincin (Anon., 2013). Antosianin bagi tubuh berfungsi sebagai antioksidan dan antikolesterol. Beras hitam apabila dimasak warnanya menjadi gelap pekat dengan rasa dan aroma yang menggugah selera makan (Suardi dan Ridwan, 2009).

Pemanfaatan beras hitam sebagai bahan pangan pokok memang belum maksimal. Pengolahan beras hitam menjadi tepung memiliki beberapa keuntungan yaitu mudah diaplikasikan ke berbagai macam produk dan umur simpan yang relatif lama. Tepung beras hitam bisa menjadi salah satu cara dalam penganekaragaman penggunaan beras hitam untuk campuran dalam pembuatan produk pangan, sehingga dapat meningkatkan nilai gizi utama berupa antioksidan dan serat dari bakpao yang dihasilkan. Penelitian ini dilakukan dengan tujuan untuk mengetahui pengaruh perbandingan tepung beras hitam dengan terigu terhadap karakteristik bakpao serta mengetahui konsentrasi tepung beras hitam yang tepat untuk menghasilkan bakpao dengan karakteristik terbaik.

\section{METODE PENELITIAN}

\section{Tempat dan Waktu}

Penelitian ini dilaksanakan di Laboratorium Analisis Pangan, Laboratorium Pengolahan Pangan, Laboratorium Biokimia dan Nutrisi, serta Laboratorium Rekayasa Proses dan Pengendalian Mutu Fakultas Teknologi Pertanian Universitas Udayana. Pelaksanaan penelitian ini dilakukan pada bulan juli sampai dengan bulan Agustus 2018.

\section{Bahan dan Alat}

Bahan-bahan yang digunakan dalam pelaksanaan penelitian ini terdiri dari bahan baku, bahan tambahan, dan bahan kimia. Bahan baku terigu (merk cakra kembar) diperoleh dari UD. Fenny dan beras hitam diperoleh dari Tiara Dewata. Bahan tambahan terdiri dari air, ragi instan merk fermipan, gula, garam, baking powder merk R\&W, mentega putih yang diperoleh dari Tiara Dewata. Bahan kimia yang digunakan dalam melakukan analisis antara lain: Methanol $95 \%$, aquades, $\mathrm{H}_{2} \mathrm{SO}_{4}$ pekat, $\mathrm{NaOH}, 2,2-$ diphenil 1-pichylhydazyl (DPPH), Alkohol $96 \%$, asam klorida $(\mathrm{HCl})$, tablet kjedahl, natrium hidroksida $(\mathrm{NaOH})$, asam borat, indikator Phenolptalin (PP), Heksan dan Dyphenyl-1 Picrylhydrazyl (DPPH).

Alat yang digunakan untuk membuat bakpao adalah loyang, sendok, ayakan tepung 60 mesh, oven (sense), timbangan digital (ACIS), waskom, kompor gas (Rinnai), dan alat pengukus. Peralatan yang digunakan untuk analisis sifat fisik dan kimia antara lain desikator, oven (Memmert), timbangan analitik (Shimadzu), aluminium foil, labu erlenmeyer (Pyrex), kertas Whatmann 42, biuret (pyrex), pipet volume (Pyrex), labu takar (Pyrex), vortex (Maxi Mix II Type 367000), mikropipet (Socorex), spektrofotometer (Thermo Scientific Genesis $10 S$ UV-Vis), cawan porselin, cawan botol timbang, pinset, spatula, labu lemak, ekstraksi soxhlet, labu kjedahl (Pyrex), destruktor muffle purnance (Daihan), pipet tetes, soxhlet, waterbath, gelas beaker (Pyrex), gelas ukur (Pyrex), pompa karet, labu ukur 
(Pyrex), tabung reaksi (Pyrex), dan lembar kuisioner untuk uji sensoris.

\section{Rancangan Percobaan}

Rancangan yang digunakan pada penelitian ini adalah Rancangan Acak Kelompok (RAK) yang terdiri dari 6 perlakuan perbandingan tepung beras hitam dengan terigu yaitu: $\mathrm{P} 0$ (0\% : 100\%), P1 (5\% : 95\%), P2 (10\% : 90\%), P3 (15\%: 85\%), P4 (20\%: 80\%), P5 $(25 \%$ : $75 \%)$. Masing-masing perlakuan diulang 3 kali sehingga diperoleh 18 unit percobaan.

\section{Pelaksanaan Penelitian}

\section{Tahap Pembuatan Tepung Beras Hitam}

Beras hitam disortir lalu dicuci sebanyak 3 kali kemudian direndam dalam air selama 3 jam. Proses selanjutnya, beras hitam yang sudah direndam tersebut ditiriskan kemudian di angin-anginkan selama 15 menit supaya air nya berkurang, setelah itu di blender hingga halus, kemudian dioven dengan suhu $60^{\circ} \mathrm{C}$ selama 6 jam, setelah dioven diayak dengan ayakan 60 mesh.

\section{Tahap Pembuatan Adonan Biang}

Proses pembuatan adonan biang dengan mencampurkan terigu, ragi dan air dengan proporsi $50 \mathrm{~g}$ terigu, $2 \mathrm{~g}$ ragi, $6 \mathrm{~g}$ gula halus, $25 \mathrm{ml}$ air kemudian diuleni hingga kalis, setelah kalis simpan adonan dalam wadah dan tutup dengan kain basah selama 1 jam.

\section{Tahap Pembuatan Bakpao}

Adonan biang yang sudah disimpan 1 jam dicampur dengan $50 \mathrm{ml}$ air dan $15 \mathrm{~g}$ gula lalu diaduk sampai rata. Ditambahkan terigu sesuai perlakuan, garam, baking powder, mentega putih dan dicampur hingga rata kemudian ditambahkan tepung beras hitam sesuai perlakuan dan diuleni hingga kalis. Adonan difermentasi selama 1 jam. Adonan yang sudah selesai difermentasi kemudian ditimbang seberat 30 g. Adonan yang sudah ditimbang difermentasikan kembali selama 30 menit. DiKukus adonan selama 15 menit.

\section{Variabel yang Diamati}

Variabel yang diamati dalam penelitian ini meliputi : analisis kadar air, kadar abu, kadar protein, kadar lemak, kadar karbohidrat, kadar serat kasar, $\mathrm{IC}_{50}$, daya kembang, tekstur dan evaluasi sensoris menggunakan uji hedonik terhadap warna, aroma, tekstur, rasa dan penerimaan keseluruhan serta uji skoring terhadap warna, tekstur dan rasa (Soekarto,1985).

\section{HASIL DAN PEMBAHASAN}

Hasil analisis kadar air, kadar abu, kadar protein, kadar lemak, kadar karbohidrat, kadar serat kasar dan $\mathrm{IC}_{50}$ tepung beras hitam dan terigu dapat dilihat pada Tabel 1 .

Tabel 1. Nilai rata-rata kadar air, kadar abu, kadar protein, kadar lemak, kadar karbohidrat, kadar serat kasar dan $\mathrm{IC}_{50}$ tepung beras hitam dan terigu

\begin{tabular}{lcc}
\hline \multicolumn{1}{c}{ Komponen } & $\begin{array}{c}\text { Tepung Beras } \\
\text { Hitam }\end{array}$ & Terigu \\
\hline Air (\%) & $7,08 \pm 0,13$ & $12,82 \pm 0,07$ \\
Abu (\%) & $1,64 \pm 0,09$ & $0,49 \pm 0,03$ \\
Protein (\%) & $9,97 \pm 0,14$ & $10,56 \pm 0,04$ \\
Lemak (\%) & $9,25 \pm 0,10$ & $5,07 \pm 0,1$ \\
Karbohidrat (\%) & $64,46 \pm 0,18$ & $71,05 \pm 0,16$ \\
Serat Kasar (\%) & $2,60 \pm 0,13$ & $2,10 \pm 0,19$ \\
IC $_{50}(\mathrm{~g} / 100 \mathrm{~g})$ & $4,36 \pm 0,06$ & nd \\
\hline
\end{tabular}

Tepung beras hitam mengandung kandungan air, abu, protein, lemak, karbohidrat, serat kasar dan $\mathrm{IC}_{50}$ masingmasing $7,08 \%, \quad 1,64 \%, \quad 9,97 \%, \quad 9,25 \%$, $64,46 \%, \quad 2,60 \%, \quad 4,36 \mathrm{~g} / 100 \mathrm{~g}$ sedangkan kandungan terigu masing-masing $12,82 \%$, $0,49 \%, 10,56 \%, 5,07 \%, 71,05 \%, 2,10 \%$ dan tidak terdeteksi.

Hasil analisis kadar air, kadar abu, kadar protein, kadar lemak, kadar karbohidrat bakpao beras hitam dapat dilihat pada Tabel 2 dan analisis kadar serat kasar, $\mathrm{IC}_{50}$, Daya kembang dan tekstur dapat dilihat pada Tabel 3. 
Tabel 2. Nilai rata-rata hasil analisis kadar air, kadar abu, kadar protein, kadar lemak, kadar karbohidrat dari bakpao beras hitam.

\begin{tabular}{cccccc}
\hline Perlakuan & $\begin{array}{c}\text { Kadar Air } \\
(\% \mathrm{bb})\end{array}$ & $\begin{array}{c}\text { Kadar Abu } \\
(\% \mathrm{bb})\end{array}$ & $\begin{array}{c}\text { Kadar Protein } \\
(\% \mathrm{bb})\end{array}$ & Kadar Lemak $(\% \mathrm{bb})$ & $\begin{array}{c}\text { Kadar Karbohidrat } \\
(\% \mathrm{bb})\end{array}$ \\
\hline P0 & $36,90 \pm 0,68 \mathrm{a}$ & $0,75 \pm 0,01 \mathrm{a}$ & $8.60 \pm 0,04 \mathrm{a}$ & $5,73 \pm 1,40 \mathrm{c}$ & $48,03 \pm 2,08 \mathrm{a}$ \\
P1 & $37,06 \pm 0,74 \mathrm{a}$ & $0,77 \pm 0,20 \mathrm{a}$ & $7,88 \pm 0,35 \mathrm{~b}$ & $5,98 \pm 0,70 \mathrm{c}$ & $48,31 \pm 1,44 \mathrm{a}$ \\
P2 & $37,44 \pm 0,48 \mathrm{a}$ & $0,85 \pm 0,13 \mathrm{a}$ & $7,46 \pm 0,60 \mathrm{ab}$ & $6,10 \pm 1,3 \mathrm{c}$ & $48,15 \pm 1,93 \mathrm{a}$ \\
P3 & $37,50 \pm 0,32 \mathrm{a}$ & $0,87 \pm 0,04 \mathrm{a}$ & $7,27 \pm 0,17 \mathrm{c}$ & $6,67 \pm 1,45 \mathrm{bc}$ & $47,68 \pm 1,00 \mathrm{a}$ \\
P4 & $37,52 \pm 0,94 \mathrm{a}$ & $0,95 \pm 0,20 \mathrm{a}$ & $7,05 \pm 0,14 \mathrm{c}$ & $8,93 \pm 1,65 \mathrm{ab}$ & $45,55 \pm 1,55 \mathrm{a}$ \\
P5 & $37,60 \pm 0,37 \mathrm{a}$ & $1,00 \pm 0,06 \mathrm{a}$ & $6,94 \pm 0,06 \mathrm{c}$ & $9,92 \pm 0,60 \mathrm{a}$ & $44,53 \pm 0,33 \mathrm{a}$ \\
\hline
\end{tabular}

Keterangan: Huruf yang berbeda dibelakang nilai rata-rata pada kolom yang sama menunjukkan perlakuan berbeda nyata $(\mathrm{P}>0,05)$. Nilai rata - rata diikuti dengan \pm standar deviasi $(\mathrm{n}=3)$

\section{Kadar Air}

Hasil sidik ragam menunjukkan bahwa perlakuan perbandingan tepung beras hitam dengan terigu berpengaruh tidak nyata $(\mathrm{P}>0,05)$ terhadap kadar air dapat dilihat pada Tabel 2.

Nilai rata-rata kadar air yang diperoleh berkisar antara 36,90\% sampai 37,60\%. Kadar air pada bakpao dipengaruhi oleh proses pengukusan. Adonan akan menyerap air guna untuk pengembangan adonan. Dalam suatu bahan pangan air dikategorikan dalam 2 tipe yaitu air bebas dan air terikat. Air bebas menunjukan dengan sifat-sifat keaktifan penuh sedangkan air terikat menunjukan air yang terikat erat dengan komponen bahan pangan. Air bebas dapat dengan mudah hilang karena proses pengukusan sedangkan air terikat sulit hilang dengan cara tersebut.

\section{Kadar Abu}

Hasil sidik ragam menunjukkan bahwa perlakuan perbandingan tepung beras hitam dengan terigu berpengaruh tidak nyata $(\mathrm{P}>0,05)$ terhadap kadar abu bakpao beras hitam. Dapat dilihat pada Tabel 2.

Nilai rata-rata kadar abu yang diperoleh berkisar antara $0,75 \%$ sampai $1,00 \%$. Kandungan kadar abu tepung beras hitam sebesar $1,64 \%$ sedangkan terigu $0,49 \%$.

\section{Kadar Protein}

Hasil sidik ragam menunjukkan bahwa perlakuan perbandingan tepung beras hitam dengan terigu berpengaruh nyata $(\mathrm{P}<0,05)$ terhadap kadar protein bakpao. Tabel 2 menunjukkan bahwa nilai rata-rata kadar protein tertinggi diperoleh pada perlakuan $0 \%$ tepung beras hitam dan $100 \%$ terigu (P0) yaitu $8,60 \%$, sedangkan nilai rata-rata terendah terdapat pada perlakuan $25 \%$ tepung beras hitam dan $75 \%$ terigu (P5) yaitu $6,94 \%$ serta berbeda tidak nyata dengan P2, P3 dan P4.

Menurunnya kandungan protein pada bakpao dikarenakan kandungan protein tepung beras hitam lebih rendah dibandingkan terigu. Tabel 1 menunjukkan tepung beras hitam mempunyai kadar protein $9,97 \%$ dan terigu $10,56 \%$.

\section{Kadar Lemak}

Hasil sidik ragam menunjukkan bahwa perlakuan perbandingan tepung beras hitam dengan terigu berpengaruh nyata $(\mathrm{P}<0,05)$ terhadap kadar lemak bakpao. Tabel 2 menunjukkan bahwa nilai rata-rata kadar lemak tertinggi diperoleh pada perlakuan 25\% tepung beras hitam dan $75 \%$ terigu (P5) yaitu $9,92 \%$ serta berbeda tidak nyata dengan $\mathrm{P} 4$, sedangkan nilai rata-rata terendah terdapat pada perlakuan $0 \%$ tepung beras hitam dan $100 \%$ terigu $(\mathrm{P} 0)$ yaitu $5,73 \%$ serta berbedatidak nyata dengan P1, P2, dan P3. Semakin tinggi penggantian terigu dengan tepung beras hitam maka kadar lemak akan semakin meningkat. Hal ini dikarenakan tepung beras hitam mempunyai kadar lemak $9,25 \%$ dan terigu $5,07 \%$. 


\section{Kadar Karbohidrat}

Hasil sidik ragam menunjukkan bahwa perlakuan perbandingan tepung beras hitam dengan terigu berpengaruh tidak nyata $(\mathrm{P}>0,05)$ terhadap kadar karbohidrat bakpao. Tabel 3 menunjukkan bahwa nilai rata-rata kadar karbohidrat yang diperoleh berkisar antara 44,53\% sampai 48,03\%. Kadar karbohidrat dihitung secara by difference sehingga dipengaruhi oleh komponen nutrisi lain. Komponen nutrisi yang mempengaruhi besarnya kandungan karbohidrat diantaranya adalah kadar air, abu, protein dan lemak.

Tabel 3. Nilai rata-rata hasil kadar serat kasar, IC50, daya kembang dan tekstur.

\begin{tabular}{ccccc}
\hline $\begin{array}{c}\text { Perlak } \\
\text { uan }\end{array}$ & $\begin{array}{c}\text { Kadar } \\
\text { Serat Kasar } \\
(\% \mathrm{bb})\end{array}$ & $\begin{array}{c}\mathrm{IC}_{50} \\
(\mathrm{~g} / 100 \mathrm{~g})\end{array}$ & $\begin{array}{c}\text { Daya } \\
\text { Kembang } \\
(\%)\end{array}$ & $\begin{array}{c}\text { Tekstur } \\
(\mathrm{N} / \mathrm{mm})\end{array}$ \\
\hline P0 & $3,10 \mathrm{a}$ & $60,14 \mathrm{a}$ & $55,82 \mathrm{a}$ & $6,08 \mathrm{~b}$ \\
P1 & $2,53 \mathrm{a}$ & $56,76 \mathrm{a}$ & $53,58 \mathrm{a}$ & $9,30 \mathrm{ab}$ \\
P2 & $2,42 \mathrm{a}$ & $41,48 \mathrm{~b}$ & $52,41 \mathrm{a}$ & $9,87 \mathrm{ab}$ \\
P3 & $2,56 \mathrm{a}$ & $34,28 \mathrm{c}$ & $42,44 \mathrm{~b}$ & $10,28 \mathrm{ab}$ \\
P4 & $2,60 \mathrm{a}$ & $26,17 \mathrm{~d}$ & $40,96 \mathrm{~b}$ & $11,27 \mathrm{a}$ \\
P5 & $2,67 \mathrm{a}$ & $24,97 \mathrm{~d}$ & $39,35 \mathrm{~b}$ & $14,07 \mathrm{a}$ \\
\hline
\end{tabular}

\section{Kadar Serat Kasar}

Hasil sidik ragam menunjukkan bahwa perlakuan perbandingan tepung beras hitam dengan terigu berpengaruh tidak nyata $(\mathrm{P}>0,05)$ terhadap kadar serat kasar bakpao. Tabel 2 menunjukkan bahwa nilai rata-rata kadar serat kasar yang diperoleh berkisar antara $2,67 \%$ sampai $3,10 \%$. Tabel 2 menunjukkan bahwa tepung beras hitam mempunyai kadar serat kasar sebesar 2,60\% sedangkan terigu $2,10 \%$.

\section{$\mathrm{IC}_{50}$}

Hasil sidik ragam menunjukkan bahwa perlakuan perbandingan tepung beras hitam dengan terigu berpengaruh sangat nyata $(\mathrm{P}<0,01)$ terhadap nilai $\mathrm{IC}_{50}$ bakpao. Tabel 3 menunjukkan bahwa nilai $\mathrm{IC}_{50}$ tertinggi diperoleh pada perlakuan $0 \%$ tepung beras hitam dan $100 \%$ terigu (P0) yaitu 60,14 $\mathrm{g} / 100 \mathrm{~g}$ serta berbeda tidak nyata dengan P1.
Nilai IC $_{50}$ terendah diperoleh pada perlakuan $25 \%$ tepung beras hitam dan $75 \%$ terigu (P5) yaitu $24,97 \mathrm{~g} / 100 \mathrm{~g}$ serta berbeda tidak nyata dengan P4. Berdasarkan data tersebut menunjukkan bahwa semakin tinggi penggantian terigu dengan tepung beras hitam maka nilai $\mathrm{IC}_{50}$ bakpao semakin rendah sehingga aktivitas antioksidannya semakin tinggi, hal ini dikarenakan kandungan senyawa bioaktif yang terdapat pada beras hitam. Beras hitam mengandung senyawa bioaktif kelompok antosianin, flavonoid, karoten dan oryzanol (Caro dkk., 2013). Senyawa-senyawa bioaktif tersebut terbukti bermanfaat untuk kesehatan seperti anti kolesterol (Hartati, 2016), pencegah kanker dan melancarkan sekresi hormonal.

\section{Daya Kembang}

Hasil sidik ragam menunjukkan bahwa perlakuan perbandingan tepung beras hitam dengan terigu berpengaruh sangat nyata $(\mathrm{P}<0,01)$ terhadap daya kembang bakpao. Tabel 3 menunjukkan bahwa nilai daya kembang tertinggi diperoleh pada perlakuan $0 \%$ tepung beras hitam dan $100 \%$ terigu (P0) yaitu sebesar 55,82\% serta berbeda tidak nyata dengan P1 dan P2. Nilai daya kembang terendah diperoleh pada perlakuan $25 \%$ tepung beras hitam dan $75 \%$ terigu (P5) yaitu $39,35 \%$ serta berbeda tidak nyata dengan $\mathrm{P} 4$ dan P3. Semakin tinggi penggantian terigu dengan tepung beras hitam maka daya kembang bakpao semakin rendah. Hal ini disebabkan karena terigu mengandung komponen penting yang membedakannya dengan bahan lain yaitu protein jenis gliadin dan glutenin yang pada kondisi tertentu dengan air dapat membentuk massa yang elastis dan dapat mengembang yang disebut gluten (Koswara, 2009).

\section{Tekstur}

Hasil sidik ragam menunjukkan bahwa perlakuan perbandingan tepung beras hitam dengan terigu berpengaruh nyata $(\mathrm{P}<0,05)$ 
terhadap tekstur bakpao yang dihasilkan. Tabel 3 menunjukkan bahwa nilai rata-rata tekstur tertinggi diperoleh pada perlakuan $25 \%$ tepung beras hitam dan $75 \%$ terigu (P5) yaitu $14,07 \mathrm{~N} / \mathrm{mm}$ serta berbeda tidak nyata dengan P1, P2, P3 dan P4, sedangkan nilai rata-rata tekstur terendah diperoleh pada perlakuan $0 \%$ tepung beras hitam dan $100 \%$ terigu (P0) yaitu $6,08 \mathrm{~N} / \mathrm{mm}$ serta berbeda tidak nyata dengan P1, P2 dan P3. Tekstur yang padat ini dipengaruhi jumlah terigu yang digunakan dalam pembuatan bakpao, semakin sedikit terigu berarti gluten juga semakin sedikit maka bakpao yang dihasilkan akan menjadi lebih padat. Gluten berperan dalam menahan gas hasil fermentasi yang akan membentuk rongga tekstur pada bakpao sehingga bakpao yang dihasilkan akan lebih empuk. (Koswara, 2009).

\section{Sifat Sensoris}

Evaluasi sifat sensoris bakpao beras hitam dilakukan dengan uji hedonik terhadap warna, aroma, takstur, rasa dan penerimaan keseluruhan serta uji skoring terhadap warna, tekstur dan rasa. Nilai rata-rata uji hedonik terhadap warna, aroma, tekstur, rasa dan penerimaan keseluruhan bakpao dapat dilihat pada Tabel 4. Nilai rata-rata uji skoring terhadap warna, rasa dan tekstur dapat dilihat pada pada Tabel 5 .

Tabel 4. Nilai rata-rata uji hedonik warna, aroma, tekstur, rasa dan penerimaan keseluruhan bakpao.

\begin{tabular}{cccccc}
\hline \multirow{2}{*}{ Perlakuan } & \multicolumn{5}{c}{ Nilai rata - rata uji hedonik } \\
\cline { 2 - 5 } & Warna & Aroma & Tekstur & Rasa & $\begin{array}{c}\text { Penerimaan } \\
\text { Keseluruhan }\end{array}$ \\
\hline P0 & $5,07 \mathrm{bcd}$ & $4,93 \mathrm{a}$ & $5,67 \mathrm{a}$ & $5,20 \mathrm{a}$ & $5,53 \mathrm{bc}$ \\
P1 & $4,73 \mathrm{~cd}$ & $5,20 \mathrm{a}$ & $5,33 \mathrm{abc}$ & $5,40 \mathrm{a}$ & $5,40 \mathrm{bc}$ \\
P2 & $5,47 \mathrm{abc}$ & $5,40 \mathrm{a}$ & $5,73 \mathrm{a}$ & $5,73 \mathrm{a}$ & $5,87 \mathrm{ab}$ \\
P3 & $6,13 \mathrm{a}$ & $5,73 \mathrm{a}$ & $5,47 \mathrm{ab}$ & $5,93 \mathrm{a}$ & $6,13 \mathrm{a}$ \\
P4 & $5,80 \mathrm{ab}$ & $5,13 \mathrm{a}$ & $5,20 \mathrm{bc}$ & $5,47 \mathrm{a}$ & $5,33 \mathrm{bc}$ \\
P5 & $4,67 \mathrm{~d}$ & $4,93 \mathrm{a}$ & $4,93 \mathrm{c}$ & $4,47 \mathrm{a}$ & $5,13 \mathrm{c}$ \\
\hline
\end{tabular}

Keterangan: Huruf yang berbeda dibelakang nilai rata-rata pada kolom yang sama menunjukkan perlakuan berbeda nyata $(\mathrm{P}>0,05)$. Kriteria hedonik: 1 (sangat tidak suka), 2 (tidak suka), 3 (agak tidak suka), 4 (biasa), 5 (agak suka), 6 (suka), 7 (sangat suka)

Tabel 5. Nilai rata-rata uji skoring warna, tekstur dan rasa bakpao beras hitam.

\begin{tabular}{cccc}
\hline \multirow{2}{*}{ Perlakuan } & \multicolumn{3}{c}{ Nilai rata - rata uji skoring } \\
\cline { 2 - 4 } & Warna & Tekstur & Rasa \\
\hline P0 & $1,00 \mathrm{e}$ & $3,73 \mathrm{a}$ & $2,07 \mathrm{f}$ \\
P1 & $2,20 \mathrm{~d}$ & $3,67 \mathrm{a}$ & $3,07 \mathrm{~d}$ \\
P2 & $2,87 \mathrm{c}$ & $3,67 \mathrm{a}$ & $3,53 \mathrm{c}$ \\
P4 & $3,60 \mathrm{~b}$ & $3,80 \mathrm{a}$ & $4,13 \mathrm{~b}$ \\
P5 & $4,07 \mathrm{a}$ & $3,40 \mathrm{a}$ & $4,47 \mathrm{a}$ \\
\hline
\end{tabular}

Keterangan: Huruf yang berbeda dibelakang nilai rata-rata pada kolom yang sama menunjukkan perlakuan berbeda nyata $(\mathrm{P}>0,05)$.

Nilai skoring warna : 1 (putih); 2 (putih keabuan); 3 (abu); 4 (abu kehitaman); 5 (hitam).

Nilai skoring tekstur : 1 (padat); 2 (agak padat); 3 (biasa); 4 (agak empuk); 5 (empuk).

Nilai skoring rasa $\quad: 1$ (tidak terasa beras hitam); 2 (agak tidak terasa beras hitam); 3 (agak terasa beras hitam); 4 (terasa beras hitam); 5 (sangat terasa beras hitam) 


\section{Warna}

Hasil sidik ragam menunjukkan bahwa perlakuan perbandingan tepung beras hitam dengan berpengaruh sangat nyata $(\mathrm{P}<0,01)$ terhadap uji hedonik dan uji skoring warna bakpao. Nilai rata-rata uji hedonik warna bakpao pada Tabel 3 menunjukkan bahwa nilai rata-rata tertinggi diperoleh pada perlakuan $15 \%$ tepung beras hitam dan $85 \%$ terigu (P3) yaitu 6,13 (suka) serta berbeda tidak nyata dengan $\mathrm{P} 2$ dan $\mathrm{P} 4$, sedangkan nilai rata-rata terendah diperoleh pada perlakuan $25 \%$ tepung beras hitam dan $75 \%$ terigu (P5) yaitu 4,67 (agak suka) serta berbeda tidak nyata dengan P0 dan P1. Panelis lebih menyukai warna bakpao dengan penambahan tepung beras beras hitam.

Tabel 4 menunjukkan bahwa nilai rata-rata tertinggi uji skoring warna bakpao diperoleh pada perlakuan $25 \%$ tepung beras hitam dan $75 \%$ terigu (P5) yaitu 4,33 (abu kehitaman) serta berbeda tidak nyata dengan $\mathrm{P} 4$, sedangkan nilai rata-rata terendah diperoleh pada perlakuan $0 \%$ tepung beras hitam dan $100 \%$ terigu $(\mathrm{P} 0)$ yaitu 1,00 (putih).

Semakin tinggi penggantian terigu dengan tepung beras hitam maka warna bakpao yang dihasilkan akan semakin kehitaman. Warna hitam pada produk ini diakibatkan oleh kandungan antosianin dalam beras hitam. Pigmen ini tergolong dalam senyawa flavonoid dan bertanggung jawab terhadap timbulnya warna oranye, jingga, merah, ungu, dan biru pada beberapa daun, bunga dan buah (Gross, 1987).

\section{Aroma}

Hasil sidik ragam menunjukkan bahwa perbandingan tepung beras hitam dengan terigu berpengaruh tidak nyata $(\mathrm{P}>0,05)$ terhadap uji hedonik aroma bakpao. Tabel 3 menunjukkan bahwa nilai rata-rata tingkat kesukaan panelis terhadap aroma bakpao berkisar antara 4,93 (agak disukai) sampai 5,73 (suka). Aroma bakpao dengan penambahan tepung beras hitam lebih disukai oleh panelis.

Menurut Meilgaard dkk., (2000) menyatakan bahwa aroma makanan timbul disebabkan oleh terbentuknya senyawa volatil yang mudah menguap, selain itu proses pemasakan yang berbeda akan menimbulkan aroma yang berbeda.

\section{Rasa}

Hasil sidik ragam menunjukkan bahwa perbandingan tepung beras hitam dengan terigu berpengaruh sangat nyata $(\mathrm{P}<0,01)$ terhadap uji hedonik dan berpengaruh tidak nyata $(\mathrm{P}>0,05)$ terhadap uji skor tekstur bakpao. Tabel 3 menunjukkan bahwa tingkat nilai rata-rata tertinggi kesukaan panelis terhadap tekstur bakpao diperoleh pada perlakuan $10 \%$ tepung beras hitam dan $90 \%$ terigu (P2) yaitu 5,73 (suka) serta berbeda tidak nyata dengan $\mathrm{P} 0, \mathrm{P} 1$ dan $\mathrm{P} 3$, sedangkan nilai rata-rata terendah diperoleh pada perlakuan 25\% tepung beras hitam dan $75 \%$ terigu (P5) yaitu 4,93 (agak suka) serta berbeda tidak nyata dengan P1 dan P4. Tingkat kesukaan panelis terhadap bakpao semakin menurun seiring dengan meningkatnya penggantian terigu dengan tepung beras hitam, hal ini dikarenakan semakin banyak penggantian terigu dengan tepung beras hitam maka bakpao yang dihasilkan akan lebih padat.

Tabel 4 menunjukkan bahwa nilai rata-rata uji skor tekstur bakpao berkisar antara 3,20 (biasa) sampai 3,80 (empuk). Tekstur pada bakpao ini dipengaruhi oleh kandungan gluten pada terigu yang menyebabkan bakpao lebih mengembang dan mempunyai tekstur yang lebih empuk. Pada penelitian ini panelis paling menyukai tekstur bakpao pada perlakuan 10\% tepung beras hitam dan 90\% terigu (P2) karena produk yang dihasilkan mempunyai tekstur yang empuk. 


\section{Rasa}

Hasil sidik ragam pada menunjukkan bahwa perbandingan tepung beras hitam dengan terigu berpengaruh tidak nyata $(\mathrm{P}>0,05)$ terhadap uji hedonik dan berpengaruh sangat nyata $(\mathrm{P}<0,01)$ terhadap uji skor rasa bakpao. Tabel 3 menunjukkan bahwa nilai rata-rata tingkat kesukaan panelis terhadap rasa bakpao berkisar antara 5,93 (suka) sampai 4,47 (biasa). Tabel 4 menunjukkan bahwa nilai rata-rata tertinggi terhadap uji skor rasa bakpao tertinggi diperoleh pada perlakuan 25\% tepung beras hitam dan $75 \%$ terigu (P5) yaitu 4,47 (terasa beras hitam), sedangkan nilai rata-rata terendah bakpao diperoleh pada perlakuan $0 \%$ tepung beras hitam dan $100 \%$ terigu (P0) yaitu 1,07 (tidak terasa beras hitam). Seiring dengan penggantian terigu dengan tepung beras hitam maka bakpao yang dihasilkan akan semakin terasa beras hitam.

\section{Penerimaan Keseluruhan}

Hasil sidik ragam menunjukkan bahwa perbandingan tepung beras hitam dengan terigu berpengaruh sangat nyata $(\mathrm{P}<0,01)$ terhadap penerimaan keseluruhan bakpao. Tabel 3 menunjukkan bahwa nilai rata-rata tertinggi tingkat kesukaan panelis terhadap penerimaan keseluruhan bakpao diperoleh pada perlakuan $15 \%$ tepung beras hitam dan $85 \%$ terigu (P3) yaitu 6,13 (suka) serta berbeda tidak nyata dengan $\mathrm{P} 2$, sedangkan nilai rata-rata terendah diperoleh pada perlakuan $25 \%$ tepung beras hitam dan $75 \%$ terigu (P5) yaitu 5,13 (agak suka) serta berbeda tidak nyata dengan $\mathrm{P} 0, \mathrm{P} 1$ dan $\mathrm{P} 4$. Penerimaan keseluruhan bakpao dipengaruhi oleh beberapa faktor seperti warna, aroma, tekstur dan rasa. Namun secara keseluruhan, bakpao beras hitam dapat diterima oleh panelis.

\section{SIMPULAN DAN SARAN}

\section{Simpulan}

Berdasarkan dari hasil penelitian:

1. Perbandingan tepung beras hitam dengan terigu berpengaruh nyata terhadap kadar protein, kadar lemak, $\mathrm{IC}_{50}$, tekstur, warna (hedonik dan skoring), tekstur (skoring), rasa (skoring) dan penerimaan keseluruhan. Berpengaruh tidak nyata terhadap kadar air, kadar abu, kadar karbohidrat, kadar serat kasar, tekstur (skoring) dan rasa (hedonik).

2. Perlakuan perbandingan $10 \%$ tepung beras hitam dengan $90 \%$ terigu menghasilkan bakpao dengan karakteristik terbaik yaitu: kadar air 37,44\%, kadar abu 0,85\%, kadar protein $7,46 \%$, kadar lemak $6,10 \%$, kadar karbohidrat 48,15\%, kadar serat kasar $2,42 \%, \mathrm{IC}_{50} 41,48 \mathrm{~g} / 100 \mathrm{~g}$, daya kembang $52,41 \%$, tekstur $9,87 \mathrm{~N} / \mathrm{mm}$, warna abu, tekstur agak empuk, rasa agak terasa beras hitam, warna dan aroma agak disukai, tekstur dan rasa serta penerimaan keseluruhan disukai.

\section{Saran}

Berdasarkan dari hasil penelitian disarankan menggunakan disarankan untuk menggunakan perbandingan $10 \%$ tepung beras hitam dengan $90 \%$ terigu dan dilakukan penelitian lebih lanjut mengenai umur simpan bakpao.

\section{DAFTAR PUSTAKA}

Anonymous. 1995. Syarat Mutu Roti Tawar. Dewan Standar Nasional. Jakarta.

Anonymous. 2007. Sedap Khusus Pemula edisi 36/VII/07. PT. Gramedia, Jakarta.

Anonymous. 2013. Karena Tingginya Antioksidan, Beras Hitam Bisa Sehatkan Jantung dan Cegah Diabetes. https://food.detik.com/info-sehat/d3072398/karena-tinggi-antioksidanberas-hitam-bisa-sehatkan-jantung-dancegah-diabetes. Diakses tanggal: 06 Juni 2018 
Gomez, K.A. dan A.A. Gomez, 1995. Prosedur Statistik untuk Penelitian Pertanian. Diterjemahkan oleh: E. Sjamsuddin dan J.S. Baharsjah. UI Press, Jakarta.

Gross, J. 1987. Pigments in Fruits. Academic Press. London.

Hardiman, I. dan Y. Asmoro 2014. 74 Resep Favorit Natural Cooking Club. Penerbit PT Gramedia Pustaka Utama, Jakarta.

Hartati, F. K. 2016 AntiHypercholesterolemia Effect of Black Rice Branin Male Winstar Rat. Proceeding International Conference. UWM Surabaya

Haryadi. 2006. Teknologi Pengolahan Beras. Penerbit UGM Press. Yogyakarta

Hu, C., J.Zawistowski, W.H.Ling, D.D.Kitts. 2003. Black Rice (Oryza Sativa L. Indica) pigmented fraction suppresses both reactive oxygen species and nitric oxide in chemical and biological model systems. J Agr Food Chem. 51: 52715277.

Ichikawa, H., T.Ichiyanagi, B.Xu, dan T.Konishi. 2001 Antioxidant activity of anthocyanin axtract from purple black rice. Journal Of Medicine Food. Vol 4(4): 211-218

Janathan. 2007. Karakteristik Fisikokimia Tepung Bekatul Serta Optimasi Formula dan Pendugaan Umur Simpan Minuman Campuran Susu Skim dan Tepung Bekatul. Skripsi. Tidak dipublikasikan. Fakultas Teknologi Pertanian IPB, Bogor.

Koswara, S. 2009. Teknologi Pengolahan Roti. Diakses pada 26 Oktober 2018.http://tekpan.unimus.ac.id/wp-
content/uploads/07/Teknologi-RotiTeori-dan-Praktek.pdf.

Meilgaard, M. G. V. Civille and B. T. Carr. 2000. Sensory Evaluation Techniques. Boca Raton, Florida : CRC Press

Narwidina, P. 2009. Pengembangan Minuman Isotonik Antosianin Beras Hitam (Oryza Sativa L. Indica) dan Efeknya Terhadap Kebugaran dan Aktivitas Antiokisdan pada Manusia Pasca Stres Fisik : A Case Control Study. Tesis. Tidak Dipublikasikan. Program Pascasarjana Fakultas Teknologi Pertanian, Universitas Gadjah Mada. Jogjakarta

Pourmorad, Fm, S.J. Hosseinimehr dan nm Shahabimajd. 2006. Antioxidant activity, phenol and flavonoid contents of some selected iranan medicinal plants. Afr J biotechnol. 5: 1142-1145.

Pradipta, I. B. Y. V., W. D. R. Putri. 2015. Pengaruh proporsi tepung terigu dan tepung kacang hijau serta substitusi dengan tepung bekatul dalam biskuit. Jurnal Pangan dan Agroindustri. 3(3): 793-802

Soekarto, S.T. 1985. Penilaian Organoleptik untuk Industri Pangan dan Hasil Pertnian. Pusat Pengembangan Teknologi Pangan, IPB, Bogor.

Suardi, D. dan I. Ridwan. 2009. Beras hitam, pangan berkhasiat yang belum populer. Warta Penelitian dan Pengembangan Pertanian 31(2): 9-10

Winarno, F.G. 2004. Kimia Pangan dan Gizi. PT Gramedia Pustaka Utama, Jakarta. 